\title{
Chronic Aluminum-Induced Motor Neuron Degeneration: Clinical, Neuropathological and Molecular Biological Aspects
}

\author{
Michael J. Strong and Ralph M. Garruto
}

\begin{abstract}
The monthly intracisternal inoculation of young adult New Zealand white rabbits with low-dose $(100 \mu \mathrm{g})$ aluminum chloride induces aggregates of phosphorylated neurofilament that mimics the intraneuronal inclusions of amyotrophic lateral sclerosis. The chronic progressive myelopathy and topographically-specific motor neuron degeneration that occurs in the absence of suppressions of neurofilament messenger RNA levels in this model contrasts with the acute fulminant encephalomyelopathy and nonspecific gene suppressions that occur subsequent to high-dose $(1000 \mu \mathrm{g})$ aluminum chloride inoculations. Further analysis of this unique model of chronic motor system degeneration can be expected to provide additional insights into the pathogenesis of amyotrophic lateral sclerosis.
\end{abstract}

RÉSUMÉ: Dégénérescence chronique du neurone moteur induite par l'aluminium : aspects cliniques, neuropathologiques et biologie moléculaire. Une inoculation mensuelle intracisternale d'une petite dose de chlorure d'aluminium $(100 \mu \mathrm{g})$, chez de jeunes lapins blancs adultes de Nouvelle Zélande, induit l'apparition d'agrégats de neurofilaments phosphorylés qui simulent les inclusions intraneuronales de la sclérose latérale amyotrophique. La myélopathie progressive chronique et la dégénérescence du neurone moteur à topographie spécifique, qui survient en l'absence de suppression des niveaux d'ARN messager du neurofilament dans ce modèle, constraste avec l'encéphalomyélopathie aiguë fulminante et la suppression génique non-spécifique qui surviennent suite à l'inoculation de hautes doses de chlorure d'aluminium $(1000 \mu \mathrm{g})$. Une analyse plus poussée de ce modèle unique ce dégénérescence chronique du système moteur laisse présager qu'on en tirera une compréhension additionnelle de la pathogenèse de la sclérose latérale amyotrophique.

Can. J. Neurol.Sci. 1991; 18: 428-431

Amyotrophic lateral sclerosis (ALS) is a relentlessly progressive, uniformly fatal disorder of the neuronal cytoskeleton affecting the upper and lower motor neurons. The disease has a world-wide distribution and increasing age-related incidence rates of 1.6 to $2.4 / 100,000.1-4$ Death occurs within 2.5 years in $50 \%$ of cases and $90-95 \%$ are deceased within the first decade. $5,6 \mathrm{As}$ a direct consequence of our studies of ALS in the Western Pacific where original incidence rates were at least 50 times higher than worldwide rates, ${ }^{7-10}$ we have undertaken the long-term development of models of chronic, experimentallyincluded neuronal degeneration, both in vivo and in vitro, in an attempt to understand the cellular and molecular pathogenic mechanisms of ALS.

Irrespective of the clinical variant studied (classical sporadic, familial or Western Pacific), the neuropathological hallmark of ALS is a loss of upper and lower motor neurons that is topographically specific (e.g. sparing of Onuf's nucleus and cranial nuclei III, IV, VI). 11 Whereas neuronal loss is a later event in the disease process, intracytoplasmic inclusions and neuroaxonal swellings consisting of interwoven skeins or parallel arrays of morphologically normal phosphorylated neurofilament within degenerating motor neurons are invariably early neuropathological findings. ${ }^{12-21}$ While there are additional neuropathological features that further distinguish between the clinical variants (e.g. paired helical filaments in Western Pacific ALS;22,23 Clarke's nucleus and dorsal spinocerebellar tract degeneration in some cases of familial ALS), ${ }^{24,25}$ these inclusions suggest that ALS is a cytoskeletal disorder with an impairment in biosynthesis or catabolism of the neurofilament triplet protein as a common biological process underlying all of the clinical variants. Extensive epidemiological, genetic, cellular and molecular studies of the Western Pacific foci of ALS have provided insights into this process and strongly implicate environmental factors in its etiology, specifically the interaction of calcium and aluminum in the disease process. ${ }^{9-10}$ The resulting hypothesis that an environmental deficiency of calcium coupled with high aluminum

From the Laboratory of Central Nervous System Studies, National Institutes of Health, Bethesda (RMG), and the Department of Clinical Neurological Sciencies, The University of Western Ontario, London (MJS)

Reprint requests to: Dr. M.J. Strong, Department of Clinical Neurological Sciences, University of Western Ontario, London, Ontario, Canada N6A 5A5 
induces a form of secondary hyperparathyrodisim accompanied by enhanced gastrointestinal absorption of aluminum has been supported by a large body of data over the past three decades, as well as by the experimental induction of neuropathological lesions reminiscent of those seen in ALS in nonhuman primates (cynomolgus monkeys and Japanese macaques) chronically fed a hypocalcemic, aluminum-supplemented diet. $26-28$

Experimentally, although aggregates of phosphorylated neurofilament with ultrastructural characteristics reminiscent of ALS can be induced with single inoculations of large $(1000 \mu \mathrm{g}$ or greater) doses of organic or inorganic aluminum compounds in a variety of experimental hosts, these conventional models of aluminum neurotoxicity are inappropriate for the study of the process of neurofilamentous degeneration in a chronic neurodegenerative disorder such as ALS. ${ }^{29}$ Invariably, these "acute" models are accompanied by a fulminant encephalopathy marked by seizures, quadraparesis and death ( 10 to 14 days post inoculation), and a diffuse, nonspecific neuronal degeneration with suppression of gene transcription not thought to occur in ALS. ${ }^{30-33}$ To circumvent these difficulties, we have developed an experimental model of a slowly progressive, aluminuminduced myelopathy that mimics to a large extent the clinical and topographic specificity of motor system degeneration in human ALS. Following repeated intracisternal inoculations of low dose $(100 \mu \mathrm{g}) \mathrm{AlCl}_{3}$ at 4 weekly intervals over the course of eight months in young adult New Zealand white rabbits (age 8-9 weeks), encephalopathic signs, widespread neuronal degeneration and suppressions of neurofilament mRNA levels seen in the "acute" model do not occur. ${ }^{34,35}$

Neuropathologically, there was extensive degeneration of spinal motor nuclei with argentophilic globular inclusions within motor neuron perikarya, dendrites and axonal processes. Neurofibrillary tangle-like argentophilic inclusions were consistently present in the gigantocellularis, reticularis, raphe and trapezoid nuclei, but only rarely present in the doral and ventral subiculum, parasubiculum and anterior thalamus, and never found in the cerebral cortex, substantia nigra, locus ceruleus, or ferebellum. Ultrastructurally, these inclusions consisted of straight or interwoven skeins of $10 \mathrm{~nm}$ filaments.

Immunocytochemically, the neurofilamentous inclusions demonstrated a spectrum of immunoreactivity with monoclonal antibodies against phosphorylated and nonphosphorylated epitopes of neurofilament subunit proteins - features reminiscent of the immunohistochemical studies of ALS reported by Schmidt et al ${ }^{18}$. While many inclusions are intensely immunoreactive with antibodies recognizing phosphorylated epitopes of neurofilament, inclusions are also present which demonstrate no immunoreactivity or are only faintly immunoreactive. Some inclusions react only to antibodies recognizing nonphosphorylated epitopes. Axonal spheroids and a variable number of intracytoplasmic inclusions $(<20 \%)$ are also uniquely immunoreactive to SMI 34, an antibody which recognized an "age-related" phosphorylation epitope of neurofilament ${ }^{36}$ but does not recognize acute aluminum-induced neurofilamentous inclusions. ${ }^{37}$

Molecular studies using our model of chronic aluminum intoxication demonstrated that alterations in gene transcription do not occur - unlike that reported for the acute model. In preliminary experiments, we have correlated the dose of $\mathrm{AlCl}_{3}$ administered $\left(1000,750,500,200\right.$ or $100 \mu \mathrm{g} \mathrm{AlCl}_{3}$ intracister- nally) with the presence of clinical deficits, extent of neurofilamentous inclusions (topographically and percentages of neurons involved per nuclear group), and the relative degree of low and intermediate weight neurofilament subunit protein mRNA suppression (compared to actin and tubulin mRNA levels by Northern blot analysis) at 48 hours post inoculation. ${ }^{35}$ Neither suppression of neurofilament mRNA levels or inclusion development occurred at the 100 to $250 \mu \mathrm{g}$ dose.

In order to demonstrate that the in vivo selectivity of neurofilamentous inclusions observed in the chronic model reflect neuron-specific thresholds of toxicity, we compared the responses to dissociated hippocampal and motor neurons in vitro to aluminum challenge. When cultured under identical conditions and similar states of maturation in a chemically-defined media, motor neurons exhibited a 10 fold greater sensitivity to aluminum toxicity than hippocampal neurons as measured by morphological criteria - e.g. cell degeneration, death or appearance of inclusions. ${ }^{38,39}$ Although electrophysiological alterations may precede the development of neuropathological changes following aluminum administration, 40 the striking disparity in sensitivity between motor neurons $\left(10 \mu \mathrm{M} \mathrm{AlCl}_{3}\right)$ and hippocampal neurons $(100 \mu \mathrm{M} \mathrm{AlCl})$ indicate neuron-specific thresholds of aluminum toxicity.

Although the exact mechanisms of aluminum intoxication as they relate to the process of neuronal degeneration have yet to be clearly defined, multiple biological effects of aluminum have been identified in human, animal and plant species. ${ }^{10,41-46}$ Those which are pertinent to altered neurofilament processing include the binding of aluminum to nuclear chromatin, 47,48 alterations in CAMP activity with subsequent increases in the rate of neurofilament phosphorylation, ${ }^{49-51}$ direct covalent binding of aluminum to phosphorylated neurofilament epitopes, 52 inhibition of calmodulin, $53-56$ inhibition of microtubule assembly, 57 impairment of slow axonal transport, ${ }^{53-61}$ and inhibition of neurofilament loading onto the axonal transport system. ${ }^{62-63}$ While these mechanisms are not mutually exclusive, they may be dependent on host genetics, the chemical form, route and frequency of aluminum administration, or the cell types analyzed. Ultimately, it is likely that one or more separate defects in neurofilament biosynthesis or catabolism lead to aberrant accumulations of neurofilament which are morphologically indistinguishable and neuron-specific. Based on our observations, and those of others demonstrating alterations in the gross morphological appearance of aluminum-induced inclusions over time, ${ }^{64-66}$ we hypothesize that, once deposited, neurofilamentous inclusions are subject to a dynamic chemical remodelling of their phosphorylation state.

Current in vivo studies are attempting to identify the mechanisms by which the phosphorylation states of neurofilamentous inclusions in chronic aluminum toxicity are altered. It is likely that the same protein kinase is responsible for normal phosphorylation and for the phosphorylation by the SMI 34 antibody (V. Ingram, personal communication). This raises the question of whether the protein kinase itself is altered in some fashion (for which kinetic studies will provide some insight) or if the site of phosphorylation is altered as suggested for tau proteins in Alzheimer disease. ${ }^{67,68}$ Ultimately, determining if aberrant protein phosphorylation is crucial to the induction of motor neuronal degeneration will provide an insight into the pathogenesis of ALS. 
Future in vivo and in vitro studies should continue to address the cellullar and molecular mechanisms of chronic low-dose aluminum intoxication leading to the induction of neurofilamentous inclusions. Such studies should not only include attempts to understand the molecular biology of altered neurofilament gene expression, transcription, translation and post-translational modification, but also the identification of aluminum transport mechanisms, neuronal metalloenzyme receptor sites and the effects of various aluminum species, chemical remodelling of aluminum complexes and calcium-aluminum interactions of the induction of neuronal degeneration.

\section{REFERENCES}

1. Juergens SM, Kurland LT, Okazaki PH, et al. ALS in Rochester, Minnestoa. 1925-1977. Neurology 1980; 30: 463-470.

2. Forsgren L, Almay BGL, Holmgren G, et al. Epidemiology of motor neuron disease in northern Sweden. Acta Neurol Scand 1983; 68: 20-29.

3. Murros K, Fogelholm R. Amyotrophic lateral sclerosis in MiddleFinland: an epidemiological study. Acta Neurol Scand 1983; 67: 41-47.

4. Hudson AJ, Davenport A, Harder WJ. The incidence of amyotrophic lateral sclerosis in southwestern Ontario, Canada. Neurology 1986; 36: 1524-1528.

5. Boman K, Meurman T. Prognosis of amyotrophic lateral sclerosis. Acta Neurol Scand 1967; 43: 489-498.

6. Rosen AD. Amyotrophic lateral sclerosis. Clinical features and prognosis. Arch Neurol 1978; 35: 638-642.

7. Shiraki HK, Yase Y. Amyotrophic lateral sclerosis in Japan. In: Vinken PJ, Bruyn GW, eds. Handbook of Clinical Neurology, Vol 22. New York: Elsevier Publishing, 1975; 353-419.

8. Gajdusek DC, Salazar AM. Amyotrophic lateral sclerosis and parkinsonian syndromes in high incidence among the Auyu and Jakai people of West New Guinea. Neurology 1982; 32: 107-126.

9. Garruto RM. Amyotrophic lateral sclerosis and Parkinsonismdementia of Guam: Clinical, epidemiological, and genetic patterns. Am J Hum Biol 1989; 1: 367-382.

10. Garruto RM. Cellular and molecular mechanisms of neuronal degeneration: Amyotrophic lateral sclerosis, parkinsonism-dementia and Alzheimer disease. Am J Hum Biol 1989; 1529-653.

11. Hirano A, Hirano M,. Dembitzer HM. Pathological variants and extent of the disease process in amyotrophic lateral sclerosis. In: Hudson AJ, ed. Amyotrophic Lateral Sclerosis. Concepts in Pathogenesis and Etiology. Toronto: University of Toronto Press, 1990: 166-192

12. Carpenter $S$. Proximal axonal enlargement in motor neuron disease. Neurology 1968; 18: 841-851.

13. Hirano A. Pathology of amyotrophic lateral sclerosis. In: Gajdusek DC, Gibbs CJ, Jr., Alpers M, eds. Slow, Latent and Temperate Virus Infections. National Institutes of Neurological Diseaes and Blindness Monograph No. 2. 1965, pp. 23-27.

14. Hirano A. Some current concepts on amyotrophic lateral sclerosis. Neurol Med (Tokyo) 1976; 4: 43-51.

15. Chou SM. Pathognomy of intraneuronal inclusions in ALS. In:. Tsubaki Y, Toyokura T, eds. Amyotrophic Lateral Sclerosis. Tokyo: University of Tokyo Press, 1979; 135-176.

16. Hirano A, Inoue K. Early pathological changes in amyotrophic lateral sclerosis. Electron microscopic study of chromatolysis, spheroids and Bunina bodies. Neurol Med (Tokyo) 1980; 13: 148-160.

17. Averback P. Unusual particles in motor neuron disease. Arch Pathol Lab Med 198 1; 105: 490-493.

18. Schmidt ML, Carden MJ, Lee VM-Y, et al. Phosphate dependent and independent neurofilament epitopes in the axonal swellings of patients with motor neuron disease and controls. Lab Invest 1987; 56: 282-294.

19. Manetto V, Sternberger NH, Perry G, et al. Phosphorylation of neurofilaments is altered in amyotrophic lateral sclerosis. J Neuropathol Exp Neurol 1988; 47: 642-653.
20. Munoz DG, Greene C, Perl DP, et al. Accumulation of phosphorylated neurofilaments in anterior horn motoneurons in amyotrophic lateral sclerosis patients. J Neuropathol Exp Neurol 1988; 47: 243-248.

21. Mizusawa $\mathrm{H}$, Matsumoto $\mathrm{S}$, Hirano A, et al. Abnormal expression of phosphorylated neurofilament proteins in sporadic and familial amyotrophic lateral sclerosis. Ann Neurol 1988; 24: 472.

22. Malamud N, Hirano A, Kurland LT. Pathoanatomic changes in amyotrophic lateral sclerosis of Guam. Arch Neurol 1961; 15: $401-415$.

23. Hirano A, Arumugasamy N, Zimmerman HM. Amyotrophic lateral sclerosis. A comparison of Guam and classical cases. Arch Neurol 1967; 16: 357-363.

24. Hirano A, Kurland LT, Sayre GP. Familial amyotrophic lateral sclerosis. Arch Neurol 1967; 16: 232-243.

25. Horton WA, Eldridge R, Brody JA. Familial motor neuron disease. Evidence for at least three different types. Neurology 1976; 26 : 400-465.

26. Yano I, Yoshida S, Uebayashi Y, et al. Experimental study of degenerative CNS disease in monkeys. In: Abstracts of the International Conference of Amyotrophic Lateral Sclerosis, Kyoto, Japan, October 29-31, 1987; 136.

27. Yase Y. Metal studies in ALS - further development. In: Tsubaki T, Yase Y, eds. Amyotrophic Lateral Sclerosis: Recent Advances in Research and Treatment. Amsterdam: Elsevier Science Publishers, 1988; 59-65.

28. Garruto RM, Shankar SK, Yanagihara R, et al. Low-calcium, high aluminum diet-induced motor neuron pathology in cynomolgus monkeys. Acta Neuropathol (Berl) 1989; 78: 210-219.

29. Strong MJ, Yanagihara R, Wolff AV, et al. Experimental neurofilamentous aggregates: Acute and chronic models of aluminuminduced encephalomyelopathy in rabbits. In: Norris FB, Rose FC, eds. Amyotrophic Lateral Sclerosis-New Advances in Toxicology and Epidemiology. London: Smith-Gordon and Company Ltd. 1990; 157-173.

30. Krekoski CA, Mathew A, Parhad IM. Neuronal gene transcription is decreased with aluminum treatment. J Cell Biol 1988; $9: 123$. 138.

31. Muma NA, Troncoso JC, Hoffman PN, et al. Aluminum neurotoxicity: Altered expression of cytoskeletal genes. Mol Brain Res 1988; 3: 115-122.

32. Parhad IM, Krekoski CA, Mathew A, et al. Neuronal gene expression in aluminum myelopathy. Cell Mol Neurobiol 1989; 9: 123138.

33. Clark AW, Tran PM, Parhad IM, et al. Neuronal gene expression in amyotrophic lateral sclerosis. J Neuropathol Exp Neurol 199; 48: 381.

34. Strong MJ, Wolff AV, Wakayama I, et al. Aluminum-induced chronic myelopathy in rabbits. Neurotoxicology 1991; 12: 9-22.

35. Nerurkar VR, Strong MJ, Wakayama I, et al. Correlation between aluminum dose, clinicopathological changes and neurofilament mRNA expression in aluminum neurotoxicity. Soc Neurosci Abstr 1990; 16: 446.

36. Blanchard BJ, Ingram VM. Age-related neurofilament phosphorylation in Alzheimer disease. Neurobiol Aging 1989; 10:253-259.

37. Sternberger NA, Sternberger LA, Ulrich J. Aberrant neurofilament phosphorylation in Alzheimer disease. Proc Natl Acad Sci USA 1985; 82: 4274-4276.

38. Strong MJ, Garruto RM. Isolation of fetal mouse motor neurons on discontinuous Percoll density gradients. In Vitro Cell Dev Biol 1989; 25: 939-945.

39. Strong MJ, Garruto RM. Aluminum neurotoxicity in vitro: A comparative analysis of dissociated fetal rabbit hippocampal and motor neuron-enriched cultures. Lab Invest 1991, in press.

40. Farnell BJ, DeBoni U, Crapper McLachlan DR. Aluminum neurotoxicity in the absence of neurofibillary degeneration in CAl hippocampal neurons in vitro. Exp Neurol 1982; 78: 241-258.

41. Foy CD, Chaney RL, White MC. The physiology of metal toxicity in plants. Ann Rev Plant Physiol 1978; 29: 511-566.

42. Roy AK, Sharma A, Talukder G. Some aspects of aluminum toxicity in plants. Bot Rev 1988; 54: 145-178. 
43. Crapper McLachlan DR. Aluminum neurotoxicity: criteria for assigning a role in Alzheimer's disease. In: Lewis TE, ed. Environmental Chemistry and Toxicology of Aluminum. Michigan: Lewis Publishers, Inc. 1989; 299-315.

44. Joshi JG. Aluminum, a neurotoxin which affects diverse metabolic reactions. BioFactors 1990; 2: 163-169.

45. Molitoris BA, Froment DH, Mackenzie TA, et al. Citrate, a major factor in the toxicity of orally administered aluminum compounds. Kidney Inter 1989; 36: 949-953.

46. Klein G, Alfrey AL, Miller NL, et al. Aluminum loading during total parenteral nutrition. Am J Clin Nutr 1982; 35: 1425-1429.

47. DeBoni U, Scott JW, Crapper DR. Intracellular aluminum binding: A histochemical study. Histochemistry 1974; 40: 31-37.

48. Karlik SJ, Eichhorn GL, Lewis PN, Crapper Dr. Interaction of aluminum species with deoxyribonucleic acid. Biochemistry 1980; 19: $5991-5998$.

49. Johnson GVW, Jope RS. Aluminum alters cyclic AMP and cyclic GMP levels but not presynaptic cholinergic markers in rat brain in vivo. Brain Res 1987; 403: 1-6.

50. Johnson GVW, Jope RS. Phosphorylation of rat brain cytoskeletal proteins is increased after orally administered aluminum. Brain Res 1988; 456: 95-103.

51. Johnson GVW, Xiahua L, Jope RS. Aluminum increases agoniststimulated cyclic AMP production in rat cerebral cortical slices. J Neurochem 1989; 53: 258-263.

52. Pierson KB, Evenson MA. $200 \mathrm{Kd}$ Neurofilament protein binds $\mathrm{Al}$, $\mathrm{Cu}$ and $\mathrm{Zn}$. Biochem Biophy Res Comm 1988; 152: 598-605.

53. Siegel N, Haug A. Aluminum interaction with calmodulin. Evidence for altered structure and function from optical and enzymatic studies. Biochimica et Biophysica Acta 1983; 744: 36-46.

54. Haug AR, Caldwell CR. Aluminum toxicity in plants. The role of plasma membrane and calmoudulin. In: St John JB, Berlin I, Jackson PC, eds. Beltsville Symposia in Agricultural Research. G. Frontiers of membrane Research in Agriculture. Totowa, New Jersey: Rowman \& Allanheld, 1985; 359-382.

55. Weis C, Haug A. Aluminum-induced conformational changes in calmodulin after the dynamics of interaction with Melittin. Arch Biochem Biophys 1987; 254: 304-312.
56. Putterill JJ, Gardner RC. Proteins with potential to protect plants from $\mathrm{Al}^{3+}$ toxicity. Biochimica et Biophysica Acta 1988; 964 : 137-145.

57. Bonhaus DW, McCormack KM, Mayor GH, et al. The effects of aluminum on microtubular integrity using in vitro and in vivo models. Toxicol Lett 1980; 6: 141-147.

58. Liwnicz BH, Kristensson K, Wisniewski HM, et al. Observations on axoplasmic transport in rabbits with aluminum-induced neurofibrillary tangles. Brain Res 1974; 80: 413-420.

59. Bates LA, Boegman RJ. The functional implications of experimentally produced neurofibillary tangles on axonal transport. Can Fed Biol Sci 1983; 26: 114.

60. Bizzi A, Crane R, Yoon M, et al. The axonal transport of neurofilaments is impaired in aluminum intoxication. J Neuropathol Exp Neurol 1984; 41: 331.

61. Troncoso JC, Hoffman PN, Griffin JW, et al. Aluminum intoxication: a disorder of neurofilament transport in motor neurons. Brain Res 1985; 342: 172-175.

62. Parhad IM, Griffin JW, Koves JF. Aluminum intoxication in the visual system: Morphological and axonal transport studies. Neurology 1984; 34: 197-198.

63. Kosik KS, McCluskey AH, Walsh FX, et al. Axonal transport of cytoskeletal proteins in aluminum toxicity. Neurochem Pathol 1985; 3: 99-108.

64. Wisniewski HM, Sturman JA, Shek JW. Aluminum chloride induced neurofibrillary changes in the developing rabbit: A chronic animal model. Ann Neurol 1980; 8: 479-490.

65. Uemura $E$. Intranuclear aluminum accumulation in chronic animals with experimenal neurofibrillary changes. Exp Neurol 1984; 85: 10-18.

66. Uemura E, Ireland WP. Synaptic density in chronic animals with experimental neurofibrillary change. Exp Neurol 1984; 85: I-9.

67. Bancher C, Brunner C, Lassman H, et al. Accumulation of abnormally phosphorylated tau precedes the formation of neurofibrillary tangles in Alzheimer's disease. Brain Res 1989; 477: 90-99.

68. Iqbal K, Grundke-Iqbal I, Zaidi T, et al. Defective brain microtubule assembly in Alzheimer disease. Lancet 1985; 2: 421-426. 